\title{
Correction to: Health risk assessment of hexachlorocyclohexane in soil, water and plants in the agricultural area of Potohar region, Punjab, Pakistan
}

\author{
Talat Ara • Waqar-Un Nisa $\cdot$ Rukhsanda Aziz $\cdot$ Muhammad Tariq Rafiq • \\ Rafaqat Ali Gill $\cdot$ Malik Tahir Hayat $\cdot$ Uzma Afridi
}

Published online: 11 April 2021

(C) The Author(s), under exclusive licence to Springer Nature B.V. part of Springer Nature 2021

\section{Correction to: \\ Environ Geochem Health \\ https://doi.org/10.1007/s10653-021-00847-9}

In the original publication of the article, in the affiliation of the authors "Waqar-Un Nisa and Muhammad Tariq Rafiq" the word "Islamic" was missed in the university name.

The correct affiliation of the authors "Waqar-Un Nisa and Muhammad Tariq Rafiq" is given below:

The original article can be found online at https:// doi.org/10.1007/s10653-021-00847-9.

T. Ara $\cdot$ R. Aziz $(\bowtie) \cdot$ U. Afridi

Department of Environmental Science, International

Islamic University, Islamabad 44000, Pakistan

e-mail: rukhsanda.aziz@iiu.edu.pk

W.-U. Nisa $(\varangle) \cdot$ M. T. Rafiq

Center for Interdisciplinary Research in Basic Sciences, International Islamic University, Islamabad 44000,

Pakistan

e-mail: waqarunnisa@iiu.edu.pk

R. A. Gill

Oil Crops Research Institute, Chinese Academy of Agricultural Sciences, Wuhan 430062, China

M. T. Hayat

Department of Environmental Sciences, COMSATS

University Islamabad, Abbottabad Campus, Abbottabad,

Pakistan
Center for Interdisciplinary Research in Basic Sciences, International Islamic University, Islamabad 44000, Pakistan.

The original article has been corrected.

Publisher's Note Springer Nature remains neutral with regard to jurisdictional claims in published maps and institutional affiliations. 